\title{
Perbaikan Instalasi Bangunan, Penyediaan Air Bersih, Pembuangan Limbah dan Dapur di Pondok Pesantren Latansa Murodak Tangerang
}

\author{
Nurhedhi Desryanto ${ }^{1}$, RB Budi Kartika W' ${ }^{2}$, Harman Sudjanto ${ }^{3}$, KGS. M. Ismail ${ }^{4}$, \\ Rubby Soebiantoro ${ }^{5}$ \\ 1,2,3,4,5Politeknik Penerbangan Indonesia Curug \\ e-mail: ${ }^{1}$ nurhedhi.desryanto@ppicurug.ac.id, ${ }^{2}$ budi.kartika@ppicurug.ac.id, \\ 3harman.sudjanto@ppicurug.ac.id, ${ }^{4}$ kgs.ismail@ ppicurug.ac.id, ${ }^{5}$ rubby.soebiantoro@ppicurug.ac.id
}

\begin{abstract}
Abstrak
Pondok Pesantren Latansa Murodak adalah salah satu pesantren di Desa Rancagong Kecamatan Legok Tangerang yang menyelenggarakan kegiatan pembelajaran agama Islam bagi santri. Pondok pesantren ini memiliki permasalahan utama yaitu kurangnya air bersih, tidak adanya tempat MCK (mandi cuci kakus) yang layak, dan tidak adanya penerangan. Permasalahan lain yang dihadapi adalah pembuangan limbah dari kamar mandi dan dapur yang tidak layak. Dengan adanya program ini, diharapkan akan membantu bagi pondok pesantren ini dalam kegiatan pembelejaran lebih nyaman sehingga santri dapat fokus menimba ilmu. Hasil fisik dari pelaksanaan Program Pengabdian Kepada Masyarakat Politeknik Penerbangan Indonesia ini adalah bangunan MCK yang layak, perbaikan lampu penerangan, pemasangan pompa dan toren air, dan tempat pembuangan limbah.
\end{abstract}

Kata Kunci : MCK, pengabdian kepada masyarakat pondok pesantren

\begin{abstract}
The Latansa Murodak Islamic Boarding School is one of the Islamic boarding schools in Rancagong Village, Legok District, Tangerang, which organizes Islamic religious learning activities for students. This Islamic boarding school has major problems, namely a lack of clean water, no proper toilet, and no lighting. Another problem faced is the improper disposal of waste from bathrooms and kitchens. With this program, it is hoped that it will help this boarding school in learning activities more comfortably so that students can focus on gaining knowledge. The physical results of the implementation of the Indonesian Aviation Polytechnic Community Service Program are proper toilets, repair of lighting lamps, installation of pumps and water toren, and waste disposal sites.
\end{abstract}

Keywords : MCK, community service, islamic boarding

\section{Pendahuluan}

Pondok pesantren latansa murodak adalah salah satu pondok pesantren di Desa Rancagong. Desa Rancagong adalah sebuah desa yang terletak di Kecamatan Legok, Tangerang, Provinsi Banten. Karena pesantren yang berdiri dengan swadana pribadi pengelola pondok dan bantuan yang jauh dari kata cukup untuk memenuhi kebutuhan hidup santri yang menginap dan santri yang belajar pada sore hari. Sehingga dengan kondisi yang ada berimbas pada penyediaan tempat hunian yang kurang memenuhi standar kesehatan. Dilihat dari kondisi saat ini terdapat beberapa sarana yang perlu diperbaiki.. Seperti pembuangan limbah yang terbuka sehingga aroma yang ditimbulkan mengganggu santri dalam 
kegiatan pembelajaran. Belum adanya tempat wudhu bagi para santri sehingga santri harus menimba dari bak penampungan. Kurangnya fasilitas penerangan yang membuat para santri tidak nyaman dalam kegiatan pembelajaran saat malam hari.

Pengabdian kepada Masyarakat merupakan suatu media untuk menghubungkan dunia pendidikan dengan masyarakat.Dalam hal ini Perguruan Tinggi diharapkan memberi manfaat kepada warga masyarakat.Salah satu upaya perguruan tinggi memberi manfaat adalah dengan kegiatan Pemberdayaan kepada Masyarakat. Politeknik Penerbangan Indonesia (PPI) sebagai salah satu lembaga pendidikan tinggi di Indonesia yang berlokasi di kecamatan Legok, kabupaten Tangerang dapat berperan serta dalam kegiatan Pemberdayaan kepada Masyarakat. Melalui kegiatan Pemberdayaan kepada Masyarakat sebagai salah satu tridharma perguruan tinggi maka PPI dapat memberi manfaat kepada masyarakat. Lebih khusus lagi manfaat yang diberikan dapat mengatasi masalah yang ada di masyarakat yaitu masalah air bersih, penerangan pondok, pembuangan limbah yang ada di pondok pesantren Latansa Murodak yang berada di Desa Rancagong Kecamatan Legok. Sehingga perlu adanya kegiatan pengabdiankepada masyarakat berupa kegiatan "Perbaikan Instalasi Bangunan, Penyediaan Air Bersih, Pembuangan Limbah dan Dapur Mandi di Pondok Pesantren Latansa Murodak Tangerang"

\section{Metode}

Untuk menyelesaikan permasalahan yang terjadi pada pondok pesantren, ada beberapa tahapan yang dilakukan pada program kemitraan masyarakat, yaitu:

1. Koordinasi dengan pihak pondok pesantren tentang pelaksanaan dari kegiatan pengabdian masyarakat ini.

2. Tahap perencanaan yang meliputi survey pada lokasi, perhitungan dan pemakaian material yang akan digunakan. Perencanaan jalur pipanisasi, perencanaan pembangunan tandon dan tempat pembuangan limbah.

3. Sosialisasi program pengabdian masyarakat kepada pihak pondok pesantren.

4. Pelaksanaan pembuatan tempat wudhu, perbaikan instalasi, tempat pembuangan limbah.

5. Evaluasi keberhasilan program

\section{PELAKSANAAN KEGIATAN}

Waktu pelaksanaan : 1 s/d 2 Desember 2020

Tempat Pelaksanaan : Pondok Pesantren Latansa Murodak Rancagong Tangerang

Tabel 1. Susunan Team

\begin{tabular}{|c|l|c|l|c|}
\hline No & \multicolumn{1}{|c|}{ Nama } & \multicolumn{1}{|c|}{ NIP } & \multicolumn{1}{c|}{ Pangkat/Gol. } & Jabatan \\
\hline 1 & KGS. M. Ismail, S.SiT, MT & 198310092008121001 & Penata Muda Tk.1 (III/b) & Ketua \\
\hline 2 & Ir. Nurhedhi Desryanto, S.Si.T., MM. & 196312041987031001 & Pembina (IV/a) & Anggota \\
\hline 3 & Drs. R.Budi Kartika, S.Pd., SSiT, MT & 196112251983031001 & Pembina / IV A & Anggota \\
\hline 4 & Drs. Harman Sudjanto, S.Si.T., M.M & 195605221977031001 & Pembina Tk.1/ IVB & Anggota \\
\hline 5 & Rubby Soebiantoro, S.ST., M.Pd & 197401082006041001 & Penata Muda Tk.1 / III B & Anggota \\
\hline
\end{tabular}

Tabel 2. Jadwal Kegiatan

\begin{tabular}{|c|c|l|}
\hline No & \multicolumn{1}{|c|}{ Hari, Tanggal } & \multicolumn{1}{c|}{ Kegiatan } \\
\hline 1. & Selasa, 01 Januari 2021 & Persiapan Kegiatan \\
\cline { 3 - 3 } & & Acara Pembukaan \\
\cline { 3 - 3 } & & Pembuatan Limbah Closet \\
\cline { 3 - 3 } & & Pembuatan Limbah Air Kamar Mandi \\
\hline
\end{tabular}




\begin{tabular}{|c|l|l|}
\hline No & \multicolumn{1}{|c|}{ Hari, Tanggal } & \multicolumn{1}{c|}{ Kegiatan } \\
\hline \multirow{3}{*}{2.} & \multirow{2}{*}{ Rabu, 02 Januari 2021 } & Pembuatan Tower Penampungan Air \\
\cline { 3 - 3 } & & Perbaikan Instalasi Listrik dan Penerangan \\
\cline { 3 - 3 } & Lanjutan Pembuatan Tower Penampungan Air \\
\cline { 3 - 3 } & Pemasangan Penampungan Air \\
\cline { 3 - 3 } & Perbaikan Instalasi Perpipaan Air Bersih \\
\cline { 3 - 3 } & Pembuatan Tempat Wudhu \\
\cline { 3 - 3 } & Pembuatan Jalan Tempat Wudhu \\
\cline { 3 - 3 } & Perbaikan Ruang Dapur \\
\hline
\end{tabular}

\section{Hasil dan Pembahasan}

1. Pelaksanaan Survey Lokasi dan Perencanaan Pembangunan

Pihak dari pondok pesantren dan tim dari PPI Curug melakukan survey lokasi dan merencanakan pembangunan sebagai awal dimulainya program.

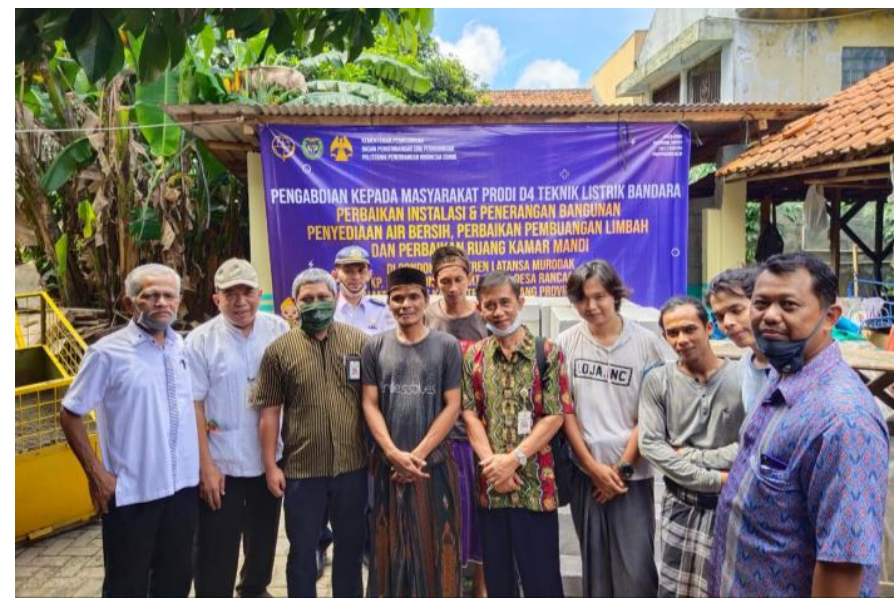

Gambar 1. Pelaksanaan survey lokasi dan Perencanaan Pembangunan

2. Pelaksanaan Pekerjaan pada Pondok Pesantren

Pada proses kegiatan ini tim mengawasi pelaksanaan pekerjaan yang ada di Pondok Pesantren seperti penyediaan air bersih, instalasi penerangan, dan pembuatan limbah.

1) Sistem Instalasi listrik dan Penerangan Bangunan

2) Perbaikan sistem penyedian air bersih yang meliputi penggantian pompa air, pemasangan penyedia penampungan air bersih, saluran instalasi air bersih dan penyedian tempat wudhu

3) Perbaikan sistem pembuangan limbah yang meliputi tempat penampungan limbah dan saluran penampungan limbah, agar dapat menciptakan lingkungan yang bersih

4) Perbaikan ruang dapur
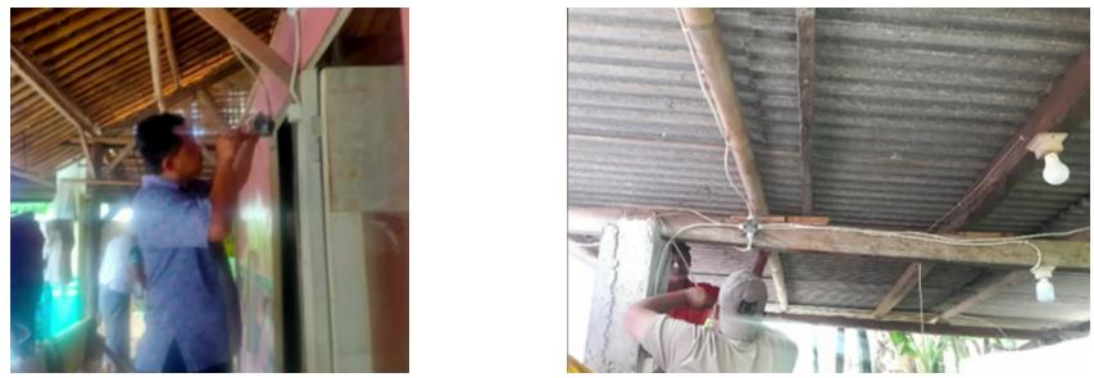

Gambar 2. Pelaksanaan instalasi listrik 


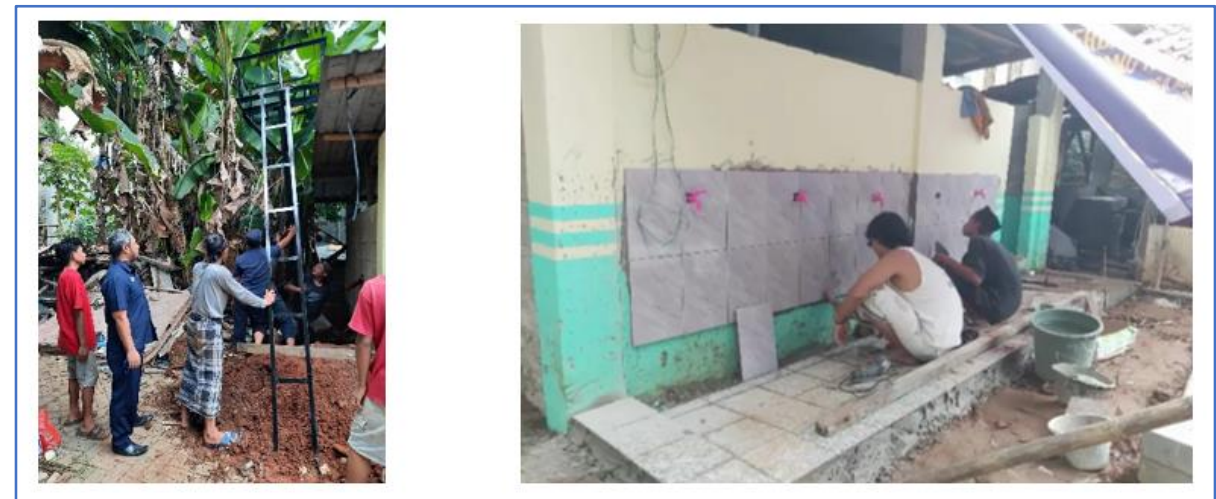

Gambar 3. Pelaksanaan pengerjaan air bersih
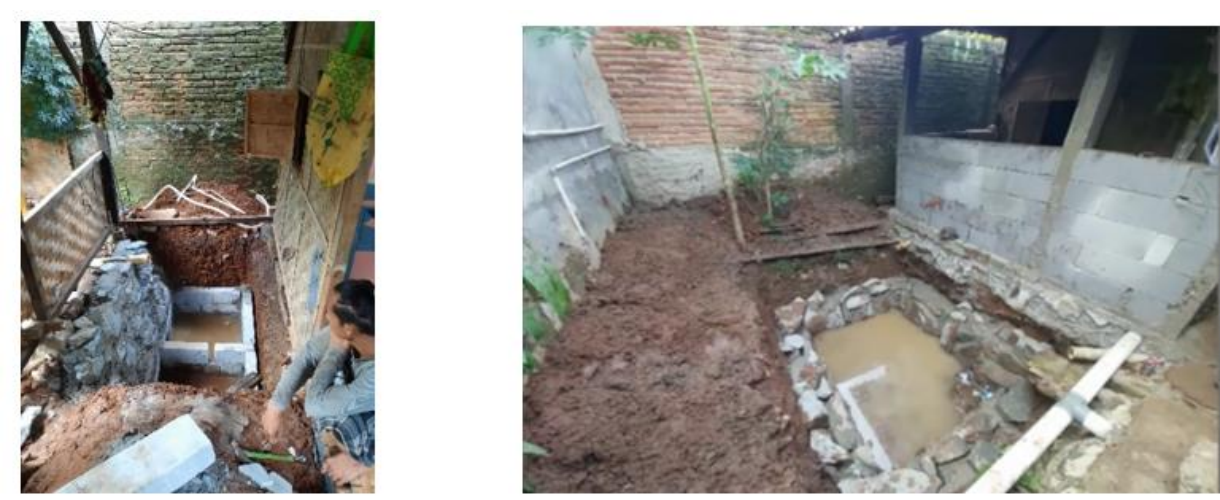

Gambar 4. Pelaksanaan pembuatan limbah
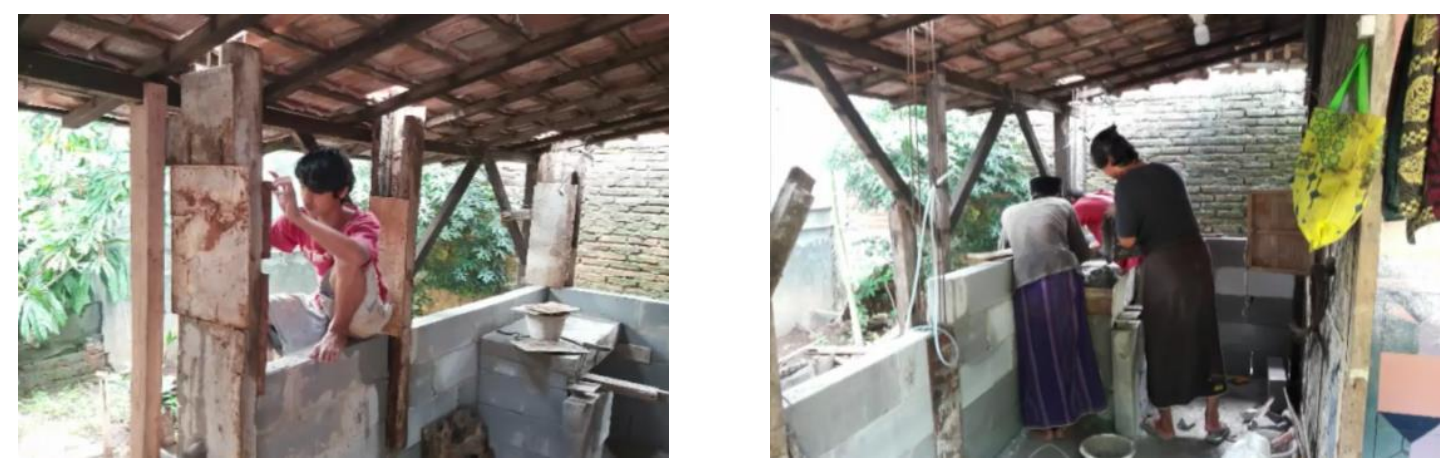

Gambar 5. Pelaksanaan Perbaikan Ruang Dapur

3. Kondisi Akhir Kegiatan

Harapan dengan pelaksanaan Pengabdian Kepada Masyarakat (PPM) tentang Perbaikan Instalasi Bangunan, Penyediaan Air Bersih, Pembuangan Limbah dan Dapur di Pondok Pesantren Latansa Murodak Tangerang akan di realisasikan guna meningkatkan kenyamanan santri dalam proses kegiatan pembelajaran. 

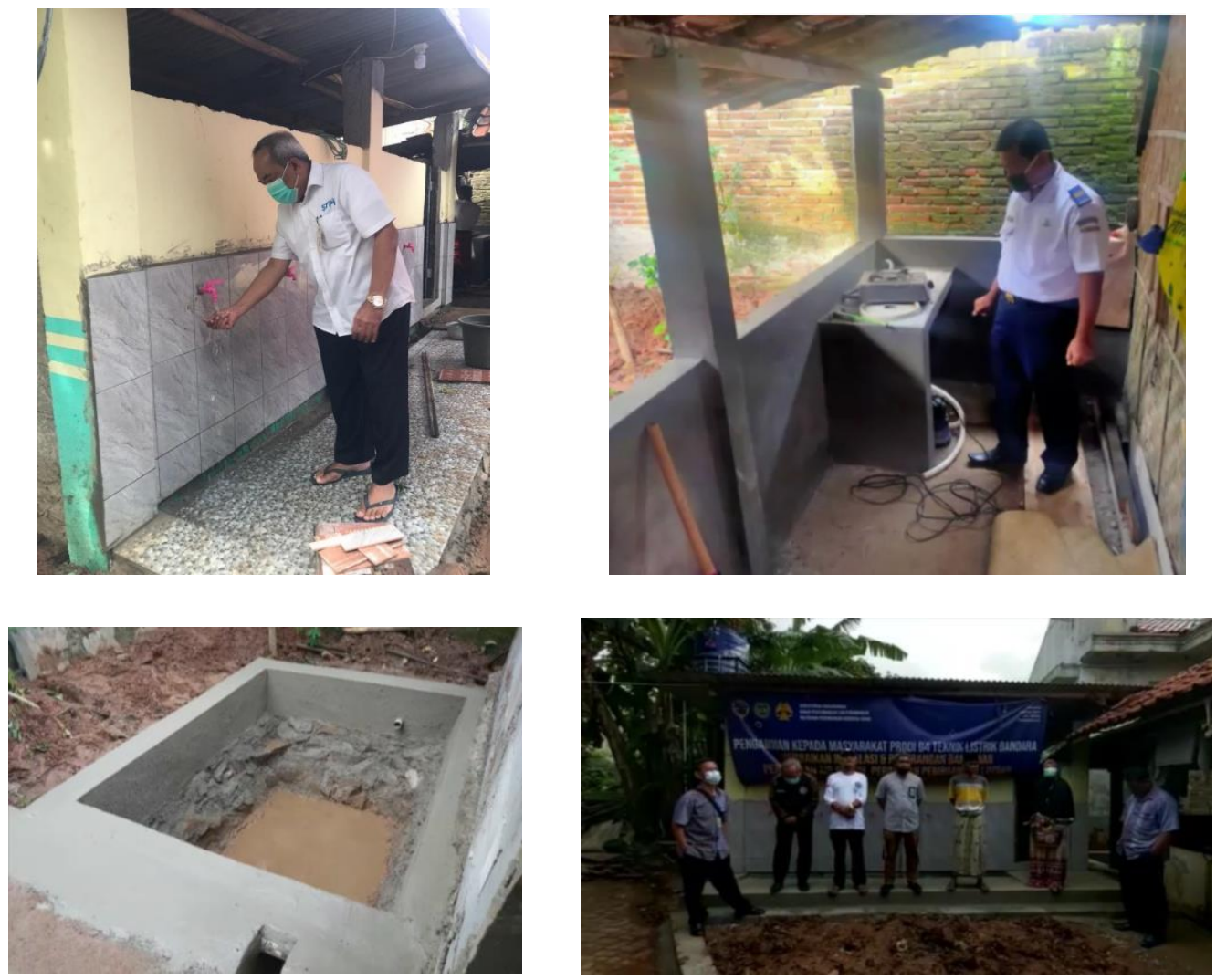

Gambar 6. Kondisi Akhir Kegiatan

\section{Kesimpulan}

Pengabdian Kepada Masyarakat (PKM) berupa Penyuluhan/Pelatihan "Perbaikan Instalasi Bangunan, Penyediaan Air Bersih, Perbaikan Pembuangan Limbah dan Kamar Mandi di Pondok Pesantren Latansa Murodak Rancagong Tangerang “ Dengan adanya perbaikan fasilitas ini diharapkan dapat membantu kenyamanan para santri dalam proses pembelajaran.

\section{Penghargaan/Ucapan terima kasih}

Kami mengucapkan terima kasih kepada Kepala Pusat Penelitian dan Pengabdian Kepada Masyarakat dan Direktur Politeknik Penerbangan Indonesia Curug yang sudah membantu kegiatan ini sehingga dapat terlaksana dengan lancar. Semoga kegiatan seperti akan bertambah banyak intensitasnya di tahun-tahun mendatang dan dapat bermanfaat bagi masyarakat sekitar kampus tercinta.

\section{Daftar Pustaka}

Modul Pembelajaran Water Pumping System, Prodi Teknik Mekanikal Bandar Udara, Politeknik Penerbangan Indonesia Curug

P. Van. Harten dan Ir. E. Setiawan, Instalasi Listrik Arus Kuat Jilid 1, Jakarta, Bina Cipta, 2019

P. Van. Harten dan Ir. E. Setiawan, Instalasi Listrik Arus Kuat Jilid 2, Jakarta, Bina Cipta, 2019 
P. Van. Harten dan Ir. E. Setiawan, Instalasi Listrik Arus Kuat Jilid 3, Jakarta, Bina Cipta, 2019

Rishel, James. (2020), Water Pumps and Pumping System. New York, USA; Mac Graw Hill

Standar Nasional Indonesia (SNI) 0225:2011. Persyaratan Umum Instalasi Listrik (PUIL) 2011, Badan Standarisasi Nasional.

Standar Nasional Indonesia (SNI) 03-7065-2005, Tata Cara Perencanaan Sistem Plambing, (2005), Badan Standarisasi Nasional.

Standar Nasional Indonesia SNI 16-7062-2004, pengukuran intensitas penerangan di tempat kerja, (2001). Badan Standarisasi Nasional.

Sularso Haruo Tahara, Pompa dan Kompresor, Pemilihan, Pemakaian dan Pemeliharaan 